\title{
The Double-Source Purchase Decisions with Substitution Under Cap and Trade Policy
}

\author{
Yi Zheng ${ }^{1,2, *}$ and Xianli Zhao ${ }^{2}$ \\ ${ }^{1}$ School of Management and Economics, University of Electronic Science and Technology of China, Chengdu, 611731, P. R. \\ China \\ ${ }^{2}$ Department of Industrial Engineering, School of Construction and Management Engineering, Xihua University, Chengdu, \\ 610039, P. R. China \\ *Corresponding author
}

\begin{abstract}
Under carbon cap-and-trade policies, double-source purchase policy of two substitutable products by a monopoly retailer is studied, obtaining optimal purchase decision and optimal pricing decision of retailers. Firstly, optimal decisions of retailers under carbon-free constraints and carbon cap-and-trade policies are analyzed. Then, the influences of carbon trade price, initial carbon quota, carbon emission and the substitutability between two products on retailer optimal decision under carbon constraints are discussed. Finally, compared with the case under carbon-free constraints, the influences of carbon cap-and-trade policies on optimal decision are analyzed. The conclusion in this paper provides theoretical supports for retailer multi-source purchase strategies.
\end{abstract} policy

Keywords-substitution;double-source purchase;cap-and-trade

\section{INTRODUCTION}

In recent years, the excessive emissions of carbon dioxide and other greenhouse gases lead to global warming, which brings a severe challenge to human survival and development, for example, sea level rise, raging heat wave, constant heavy rainfall, and drought [1]. Studies have demonstrated that global warming may be caused by man-made reasons for at least $90 \%$. Enterprises compete in the supply chain and carbon footprints are managed in production, transportation, inventory, sales and the whole process. For example, Wal-Mart, TESCO and HP all design environment networks with low-carbon supply chain by low-carbon supply chain management, establish multi-source purchase mechanism, fully utilize vehicle energy efficiency, control carbon emission and measure carbon footprint, further realizing the optimization of the whole carbon emission process of the supply chain. IBM also utilizes carbon thermograph to analyze the carbon footprint of the global supply chain network and implements multi-channel and multi-source three-dimensional purchase, further realizing energy conservation and emission reduction of the supply chain[2]. For enterprises, aside from carbon emission in the production link, transportation is the second largest pollution source and almost $50 \%$ carbon emission is generated in the transportation link[3]. Therefore, the study on retailer multi-source purchase decisions under low-carbon policies is of important theoretical value and practical significance.

Many scholars are occupied in the retailer purchase decision of the supply chain. Hua[4] studied the optimal order quantity of enterprises under carbon trade policies. Chen et al.[5]utilized EOQ model to make numerical analysis. Also, the conditions of carbon emission reduction by modifying the order quantity, as well as the influence factors of carbon emission reduction and cost increase were studied. Choi[6]analyzed the influences of carbon cap-and-trade policies on retailer purchase source selection under wholesale price and price subsidy contracts. In the study of Jin et al.[7]the influences of carbon cap-and-trade and other carbon emission policies on the supply chain network design and retailerlogistics transportation were explored and the numerical analysis indicated that different carbon emission policies had direct influences on transportation cost and emission reduction effects. Rosic et al. [8] considered (domestic and overseas) retailers faced with double-source purchase and studied the optimal order quantity and optimal order source selection under carbon cap-and-trade and carbon tax policies and compared the control effects on carbon emission under two carbon emission policies. For single-enterprise decision under low-carbon policies, He et al.[9] studied EQQ based model and studied the production quantity of manufacturing enterprises under carbon tax policies and carbon cap-and-trade policies. The study found that the optimal production quantity under carbon cap-and-trade depended on carbon emission permits trade and these two policies were not always superior to each other in carbon emission reduction. Zhang et al.[10] constructed a production and inventory decision optimization model of manufacturing enterprises considering carbon emission permits trade on the basis of the newsboy model. Through the solution method for this model, the optimal inventory policy for enterprises faced with random demands under cap-and-trade policies was obtained. Hong et al.[11]constructed a production model of environment-friendly manufacturers under cap and trade policy. Also, the optimal production and carbon emission permits trade strategy of manufacturers under given carbon emission quota were solved by dynamic programming method and the influences of carbon emission permits trade price on manufacturer optimal strategy were analyzed. Giraud-Carrier[12] simulated an enterprise operating decision process under three main emission policies (cap, cap and trade, and tax) and pointed out that under any regulation policies, it was inevitable for production to reduce. However, when the negative effects of pollution are very huge, these regulation policies will improve the whole social welfare. The above literatures all establish foundation for this study. 
Considering carbon cap and trade policies, the study on retailer multi-source purchase is for great practical value to low-carbon retailer's purchase and pricing and important reference significance to the formulation of carbon emission policies.

\section{PROBlEM DESCRIPTION AND HYPOTHESIS}

This paper considers a monopoly retailer's purchase of homogeneous substitutable products of manufacturer A and manufacturer $B$ in two different regions in the same trade market. Suppose manufacturer A produces $S_{1}$ and manufacturer $B$ produces $S_{2}$. Under carbon cap and trade policies, the government distributes certain initial carbon quotas in the transportation and saleslinks to reduce carbon emission of enterprises in each link of the supply chain. If the total carbon emission in the transportation and saleslinks is greater than the initial carbon quotas, retailers must purchase extra carbon emission permits from the carbon emission trading market. If the total carbon emission in the transportation and saleslinks is lower than the initial carbon quotas, retailers can sell the spare carbon emission permits and make a profit. Carbon emission trade price is determined by carbon emission trade market, belonging to exogenous variable. The government formulates monocycle carbon cap according to the production in the last period and unit product emission in different industries, which is irrelevant to the production in the current period, belonging to exogenous variable. It cannot be passed on to the next period.

When manufacturers give no investment on green technology, its technology level of unit product in production and inventory links is unchanged and its carbon emission remains unchanged. Thus, this paper only takes the carbon emission in the transportation and sales links into consideration, instead of those in production, inventory and other links. Products are completely sold in sales season, so product stockout and order lead time are not considered. Due to the limits of retailer transportation conditions and inventory capacity, the maximum purchase quantity of retailers is $\mathrm{k}$. Therefore, when retailers make purchase decisions, the wholesale price of two manufacturers and also carbon emission costs in the transportation and sales links should be considered. 1.

Parameters and variables in this study are shown as Table

TABLE I. SYMBOLS AND THEIR DEFINITIONS

\begin{tabular}{cl}
\hline Symbols & \multicolumn{1}{c}{ definition } \\
\hline $\mathrm{q}_{1}, \mathrm{q}_{2}$ & Retailer order quantity/market demands of product $\mathrm{S}_{1}$ and \\
& $\mathrm{S}_{2} ;$ \\
$\mathrm{w}_{\mathrm{s} 1}, \mathrm{w}_{\mathrm{s} 2}$ & Wholesale price and unit product $\mathrm{S}_{1}$ and $\mathrm{S}_{2}$ formulated by \\
$\mathrm{p}_{1}, \mathrm{p}_{2}$ & manufacturers; \\
$\mathrm{C}_{\mathrm{e}}$ & Retail price of two unit products; \\
$\mathrm{e}_{\mathrm{s} 1}, \mathrm{e}_{\mathrm{s} 2}$ & Carket trade price of unit carbon emission permit; \\
$\mathrm{A}$ & logistic link ande $\mathrm{s}_{\mathrm{s} 1}>\mathrm{e}_{\mathrm{s} 2}$; \\
$\pi$ & Carbon quota of the government to retailers; \\
\hline
\end{tabular}
are,

$$
\mathrm{q}_{1}=\alpha_{1}-\mathrm{p}_{1}+\beta \mathrm{p}_{2}, \quad \mathrm{q}_{2}=\alpha_{2}-\mathrm{p}_{2}+\beta \mathrm{p}_{1}
$$

Where, $\alpha_{1}, \alpha_{2}$ and $\beta$ are constant, and $\beta>0 . \beta$ is the mutually substitutability between two products. Considering the greater influences of product price than interactive price on demands, it is supposed $\beta<1$.

\section{Double-Source Purchase Decision Model OF Substitutable Products Under CARbon-Free CONSTRAINTS}

Under carbon-free constraints, retailers do not consider carbon emission in sales and transportation links and retailer decision order is as follows. First of all, retailers determine total purchase quantity $\mathrm{k}$ according to self-conditions to maximize their profits. Then, they decide optimal purchase quantity of two products according to market demand information. Suppose purchase quantity is $\mathrm{k}$, retailer profit function can be expressed as,

$$
\left\{\begin{array}{c}
\max \left(\mathrm{p}_{1} \mathrm{q}_{1}+\mathrm{p}_{2} \mathrm{q}_{2}-\mathrm{w}_{\mathrm{s} 1} \mathrm{q}_{1}-\mathrm{w}_{\mathrm{s} 2} \mathrm{q}_{2}\right) \\
\mathrm{q}_{1}+\mathrm{q}_{2} \leq \mathrm{k} \\
\mathrm{p}_{1}=\alpha_{1}-\mathrm{q}_{1}+\beta \mathrm{p}_{2} \\
\mathrm{p}_{2}=\alpha_{2}-\mathrm{q}_{2}+\beta \mathrm{p}_{1}
\end{array}\right.
$$

Proposition 1 Under carbon-free constraints, the maximum purchase quantity of retailers is $\mathrm{k}^{*}=\frac{\alpha_{1}+\alpha_{2}-(1-\beta)\left(\mathrm{w}_{\mathrm{s} 1}+\mathrm{w}_{\mathrm{s} 2}\right)}{2}$, optimal purchase strategy is $\left(\mathrm{q}_{1}^{*}, \mathrm{q}_{2}^{*}\right)=\left(\frac{\alpha_{1}+\beta \mathrm{w}_{\mathrm{s} 2}-\mathrm{w}_{\mathrm{s} 1}}{2}, \frac{\alpha_{2}+\beta \mathrm{w}_{\mathrm{s} 1}-\mathrm{w}_{\mathrm{s} 2}}{2}\right)$, and optimal price is $\left(\mathrm{p}_{1}^{*}, \mathrm{p}_{2}^{*}\right)=\left(\frac{\alpha_{1}+\beta \alpha_{2}}{2\left(1-\beta^{2}\right)}+\frac{\mathrm{w}_{\mathrm{s} 1}}{2}, \frac{\beta \alpha_{1}+\alpha_{2}}{2\left(1-\beta^{2}\right)}+\frac{\mathrm{w}_{\mathrm{s} 2}}{2}\right)$.

Proof: The solution of Formula (2) can be seen as a multivariate function seeking for multi-conditionextremal problem. The optimal purchase quantities of products $\mathrm{S} 1$ andS $2, \mathrm{q}_{1}^{*}$ andq ${ }_{2}^{*}$, can be solved.

If $\mathrm{q}_{1}+\mathrm{q}_{2}<\mathrm{k}$, the extremal occurs in the condition region. After it is solved, the optimal purchase quantity can be expressed as,

$$
\left(\mathrm{q}_{11}^{*}, \mathrm{q}_{21}^{*}\right)=\left(\frac{\alpha_{1}+\beta \mathrm{w}_{\mathrm{s} 2}-\mathrm{w}_{\mathrm{s} 1}}{2}, \frac{\alpha_{2}+\beta \mathrm{w}_{\mathrm{s} 1}-\mathrm{w}_{\mathrm{s} 2}}{2}\right)
$$

If $\mathrm{q}_{1}+\mathrm{q}_{2}=\mathrm{k}$, the extremal occurs on the margin of the condition region. $\mathrm{q}_{1}+\mathrm{q}_{2} \leq \mathrm{q}_{12}^{*}+\mathrm{q}_{22}^{*}$, namely,

$$
\mathrm{k} \leq \frac{\alpha_{1}+\alpha_{2}-(1-\beta)\left(\mathrm{w}_{\mathrm{s} 1}+\mathrm{w}_{\mathrm{s} 2}\right)}{2}
$$

It is not easy to infer that extremal occurs in the region. If $\mathrm{k}>\frac{\alpha_{1}+\alpha_{2}-(1-\beta)\left(\mathrm{w}_{\mathrm{s} 1}+\mathrm{w}_{\mathrm{s} 2}\right)}{2}$, the optimal wholesale quantity is,

$$
\left(\mathrm{q}_{12}^{*}, \mathrm{q}_{22}^{*}\right)=\left(\begin{array}{l}
\frac{\alpha_{1}-\alpha_{2}-\left(\mathrm{w}_{\mathrm{s} 1}-\mathrm{w}_{\mathrm{s} 2}\right)(1+\beta)+2 \mathrm{k}}{4}, \\
\frac{\alpha_{2}-\alpha_{1}+\left(\mathrm{w}_{\mathrm{s} 1}-\mathrm{w}_{\mathrm{s} 2}\right)(1+\beta)+2 \mathrm{k}}{4}
\end{array}\right)
$$

According to Formula (1), the retail price of product S1 andS2can be solved. 


$$
\left\{\begin{array}{l}
\mathrm{p}_{1}=\frac{\alpha_{1}+\beta \alpha_{2}-\mathrm{q}_{1}-\beta \mathrm{q}_{2}}{1-\beta^{2}} \\
\mathrm{p}_{2}=\frac{\alpha_{2}+\beta \alpha_{1}-\mathrm{q}_{2}-\beta \mathrm{q}_{1}}{1-\beta^{2}}
\end{array}\right.
$$

According to $\mathrm{p}_{1}>\mathrm{w}_{\mathrm{s} 1}, \mathrm{p}_{2}>\mathrm{W}_{\mathrm{s} 2}$, the wholesale prices of two products satisfy,

$$
\alpha_{1}+\alpha_{2}>(1-\beta)\left(w_{\mathrm{s} 1}+w_{\mathrm{s} 2}\right)
$$

When $\mathrm{k}>\frac{\alpha_{1}+\alpha_{2}-(1-\beta)\left(\mathrm{w}_{\mathrm{s} 1}+\mathrm{w}_{\mathrm{s} 2}\right)}{2}$,

$\left(\mathrm{q}_{11}^{*}, \mathrm{q}_{21}^{*}\right)=\left(\frac{\alpha_{1}+\beta \mathrm{w}_{\mathrm{s} 2}-\mathrm{w}_{\mathrm{s} 1}}{2}, \frac{\alpha_{2}+\beta \mathrm{w}_{\mathrm{s} 1}-\mathrm{w}_{\mathrm{s} 2}}{2}\right)$ and the profit of retailers is,

$$
\begin{aligned}
\pi_{1}(\mathrm{k})= & \frac{1}{4\left(1-\beta^{2}\right)}\left(\alpha_{1}{ }^{2}+\alpha_{2}{ }^{2}+2 \beta \alpha_{1} \alpha_{2}\right)- \\
& \frac{1}{4}\left(2 \alpha_{1} \mathrm{w}_{\mathrm{s} 1}+2 \alpha_{2} \mathrm{w}_{\mathrm{s} 2}\right)+\frac{2 \beta \mathrm{w}_{\mathrm{s} 1} \mathrm{w}_{\mathrm{s} 2}-\mathrm{w}_{\mathrm{s} 1}{ }^{2}-\mathrm{w}_{\mathrm{s} 2}{ }^{2}}{4}
\end{aligned}
$$

Whenk $\leq \frac{\alpha_{1}+\alpha_{2}-(1-\beta)\left(\mathrm{w}_{\mathrm{s} 1}+\mathrm{w}_{\mathrm{s} 2}\right)}{2}$,

$$
\left(\mathrm{q}_{12}^{*}, \mathrm{q}_{22}^{*}\right)=\left(\frac{\alpha_{1}-\alpha_{2}-\left(\mathrm{w}_{\mathrm{s} 1}-\mathrm{w}_{\mathrm{s}}\right)(1+\beta)+2 \mathrm{k}}{4}, \frac{\alpha_{2}-\alpha_{1}+\left(\mathrm{w}_{\mathrm{s} 1}-\mathrm{w}_{\mathrm{s} 2}\right)(1+\beta)+2 \mathrm{k}}{4}\right) \text {, the }
$$
profit of retailers, $\pi_{2}(\mathrm{k})$ is satisfied,

$$
\frac{\mathrm{d} \pi_{2}(\mathrm{k})}{\mathrm{dk}}=-\frac{\mathrm{k}}{2(1+\beta)}+\frac{\alpha_{1}+\alpha_{2}-\mathrm{k}}{2(1-\beta)}-\frac{\mathrm{w}_{\mathrm{s} 1}+\mathrm{w}_{\mathrm{s} 2}}{2} \geq 0, \frac{\mathrm{d}^{2} \pi_{2}(\mathrm{k})}{\mathrm{dk}^{2}}=-\frac{1}{1-\beta^{2}}<0 \quad, \quad \text { so }
$$
retailers have optimal order quantity $\mathrm{k}^{*}$ at the end of the internal. Suppose $\frac{\mathrm{d} \pi_{2}(\mathrm{k})}{\mathrm{dk}}=0$, the optimal purchase quantity of retailers when $\mathrm{k} \leq \frac{\alpha_{1}+\alpha_{2}-(1-\beta)\left(\mathrm{w}_{\mathrm{s} 1}+\mathrm{w}_{\mathrm{s} 2}\right)}{2}$ can be expressed as,

$$
\mathrm{k}^{*}=\frac{\alpha_{1}+\alpha_{2}-(1-\beta)\left(\mathrm{w}_{\mathrm{s} 1}+\mathrm{w}_{\mathrm{s} 2}\right)}{2}
$$

For the above two conditions, $\mathrm{k}^{*}$ is the optimal purchase quantity of retailers. The optimal purchase quantities and optimal pricing strategies of two products respectively are,

$$
\begin{aligned}
& \left(q_{1}^{*}, q_{2}^{*}\right)=\left(\frac{\alpha_{1}+\beta w_{s 2}-w_{s} 1}{2}, \frac{\alpha_{2}+\beta w_{s 1}-w_{s}}{2}\right)(3) \\
& \left(p_{1}^{*}, p_{2}^{*}\right)=\left(\frac{\alpha_{1}+\beta \alpha_{2}}{2\left(1-\beta^{2}\right)}+\frac{w_{s} 1}{2}, \frac{\beta \alpha_{1}+\alpha_{2}}{2\left(1-\beta^{2}\right)}+\frac{w_{s 2}}{2}\right)(4)
\end{aligned}
$$

End.

Proposition 1 proves that under carbon-free constraints, the optimal purchase of a product has a negative correlation with its wholesale price while positive correlation with the wholesale price of its substitutable product. Thus, these two products mutually restrict for their wholesale prices. The optimal pricing strategy of a product has a positive correlation with the wholesale price of the product.

\section{Retailer Double-Source Purchase Decision Model of Substitutable Products Under CAP-AND-TRADE POLICY}

Under carbon cap and trade policies, retailers should consider the carbon emission cost of two products in sales and transportation links, which may influence retailer optimal decisions.

Proposition 2 Under carbon cap-and-trade policies, when retailers purchase two substitutable products by two manufacturers, the optimal order strategy is, $\mathrm{q}_{\mathrm{c} 1}^{*}=\frac{\alpha_{1}+\beta \mathrm{w}_{\mathrm{s} 2}+\beta \mathrm{C}_{\mathrm{e}} \mathrm{e}_{\mathrm{s} 2}-\mathrm{w}_{\mathrm{s} 1}-\mathrm{C}_{\mathrm{e}} \mathrm{e}_{\mathrm{s} 1}}{2}, \mathrm{q}_{\mathrm{c} 2}^{*}=\frac{\alpha_{2}+\beta \mathrm{w}_{\mathrm{s} 1}+\beta \mathrm{C}_{\mathrm{e}} \mathrm{e}_{11}-\mathrm{w}_{\mathrm{s} 2}-\mathrm{C}_{\mathrm{e}} \mathrm{e}_{\mathrm{s} 2}}{2}$, and the optimal pricing strategy $\operatorname{isp}_{\mathrm{c} 1}^{*}=\frac{\alpha_{1}+\beta \alpha_{2}}{2\left(1-\beta^{2}\right)}+\frac{\mathrm{w}_{\mathrm{s} 1}+\mathrm{C}_{\mathrm{e}} \mathrm{e}_{\mathrm{s} 1}}{2}, \quad \mathrm{p}_{\mathrm{c} 2}^{*}=\frac{\beta \alpha_{1}+\alpha_{2}}{2\left(1-\beta^{2}\right)}+\frac{\mathrm{w}_{\mathrm{s} 2}+\mathrm{C}_{\mathrm{e}} \mathrm{e}_{\mathrm{s} 2}}{2}$.

Proof: Under carbon cap-and-trade policies, the retailer profit is shown as Formula (5).

$$
\pi_{\mathrm{c}}=\mathrm{p}_{1} \mathrm{q}_{1}+\mathrm{p}_{2} \mathrm{q}_{2}-\mathrm{w}_{\mathrm{s} 1} \mathrm{q}_{1}-\mathrm{w}_{\mathrm{s} 2} \mathrm{q}_{2}-\mathrm{C}_{\mathrm{e}} \mathrm{e}_{\mathrm{s} 1} \mathrm{q}_{1}-\mathrm{C}_{\mathrm{e}} \mathrm{e}_{\mathrm{s} 2} \mathrm{q}_{2}+\mathrm{AC}_{\mathrm{e}} \quad \mathrm{q}_{1}=\alpha_{1}-\mathrm{p}_{1}+\uparrow
$$

The optimal order quantity is,

$$
\left\{\begin{array}{l}
\mathrm{q}_{\mathrm{c} 1}^{*}=\frac{\alpha_{1}+\beta \mathrm{w}_{\mathrm{s} 2}+\beta \mathrm{C}_{\mathrm{e}} \mathrm{e}_{\mathrm{s} 2}-\mathrm{w}_{\mathrm{s} 1}-\mathrm{C}_{\mathrm{e}} \mathrm{e}_{\mathrm{s} 1}}{2} \\
\mathrm{q}_{\mathrm{c} 2}^{*}=\frac{\alpha_{2}+\beta \mathrm{w}_{\mathrm{s} 1}+\beta \mathrm{C}_{\mathrm{e}} \mathrm{e}_{\mathrm{s} 1}-\mathrm{w}_{\mathrm{s} 2}-\mathrm{C}_{\mathrm{e}} \mathrm{e}_{\mathrm{s} 2}}{2}
\end{array}\right.
$$

$$
\begin{aligned}
\mathrm{k}_{\mathrm{c}}^{*}=\mathrm{q}_{\mathrm{c} 1}^{*}+\mathrm{q}_{\mathrm{c} 2}^{*}= & \\
& \frac{\alpha_{1}+\alpha_{2}+(\beta-1)\left(\mathrm{w}_{\mathrm{s} 1}+\mathrm{w}_{\mathrm{s} 2}\right)+\beta \mathrm{C}_{\mathrm{e}}\left(\mathrm{e}_{\mathrm{s} 1}+\mathrm{e}_{\mathrm{s} 2}\right)-\mathrm{C}_{\mathrm{e}} \mathrm{e}_{\mathrm{s} 1}-\mathrm{C}_{\mathrm{e}} \mathrm{e}_{\mathrm{s} 2}}{2}
\end{aligned}
$$

According to Formula (6), the optimal retail price can be calculated.

$$
\left\{\begin{array}{l}
\mathrm{p}_{\mathrm{c} 1}^{*}=\frac{\alpha_{1}+\beta \alpha_{2}}{2\left(1-\beta^{2}\right)}+\frac{\mathrm{w}_{\mathrm{s} 1}+\mathrm{C}_{\mathrm{e}} \mathrm{e}_{\mathrm{s} 1}}{2} \\
\mathrm{p}_{\mathrm{c} 2}^{*}=\frac{\beta \alpha_{1}+\alpha_{2}}{2\left(1-\beta^{2}\right)}+\frac{\mathrm{w}_{\mathrm{s} 2}+\mathrm{C}_{\mathrm{e}} \mathrm{e}_{\mathrm{s} 2}}{2}
\end{array}\right.
$$

End.

Proposition 2 proves that under carbon cap-and-trade policies, the optimal retail price of a product has a positive correlation with carbon emission bargain price and wholesale price. The optimal purchase quantity of a product has a positive correlation with carbon emission and wholesale price of substitutable products while negative correlation with its carbon emission and wholesale price. Because of the substitutability, the optimal purchase quantities of two products mutually restrict for their carbon emissions and wholesale prices. Compared with proposition 1 under carbon-free constraints, product cost includes the wholesale price as well as carbon emission cost due to carbon trading.

Proportion 3 Under carbon cap-and-trade policies,
(1) $\frac{\mathrm{dk}_{\mathrm{c}}^{*}}{\mathrm{dw}_{\mathrm{s} 1}}=\frac{\mathrm{dk}_{\mathrm{c}}^{*}}{\mathrm{dw}_{\mathrm{s} 2}}<0$; (2)
(2) $\frac{\mathrm{dk}_{\mathrm{c}}^{*}}{\mathrm{~d} \beta}=\frac{\mathrm{w}_{\mathrm{s} 1}+\mathrm{w}_{\mathrm{s} 2}+\mathrm{C}_{\mathrm{e}} \mathrm{e}_{\mathrm{s} 1}+\mathrm{C}_{\mathrm{e}} \mathrm{e}_{\mathrm{s} 2}}{2}>0$;
(3) $\frac{\mathrm{dq}_{\mathrm{c1}}^{*}}{\mathrm{dw}_{\mathrm{s} 1}}<0, \frac{\mathrm{dq}_{\mathrm{c} 2}^{*}}{\mathrm{dw}_{\mathrm{s} 2}}<0$,
(4) $\frac{d q_{c 1}^{*}}{d w_{s 2}}>0, \frac{d q_{c 2}^{*}}{d w_{s 1}}>0$,
(5) $\frac{d q_{c 1}^{*}}{d \beta}=\frac{d q_{c 2}^{*}}{d \beta}>0$. 
Proof: According to the above conclusion, it is supposed that under carbon cap-and-trade policies, the total purchase quantityis $\mathrm{k}_{\mathrm{c}}^{*}$, and then,

$\mathrm{k}_{\mathrm{c}}^{*}=\mathrm{q}_{\mathrm{c} 1}^{*}+\mathrm{q}_{\mathrm{c} 2}^{*}=$

$\frac{\alpha_{1}+\alpha_{2}+(\beta-1)\left(w_{s}+w_{s}\right)+\beta C_{e}\left(e_{s} 1+e_{s}\right)-C_{e} e_{s} 1-C_{e} e_{s 2}}{2}(8)$

According to Formula (8), the derivative is taken, obtaining $\frac{\mathrm{dk}_{\mathrm{c}}^{*}}{\mathrm{dw}_{\mathrm{s} 1}}=\frac{\mathrm{dk}_{\mathrm{c}}^{*}}{\mathrm{dw}_{\mathrm{s} 2}}=-\frac{1-\beta}{2}<0$, namely, the total order quantity of retailers has a negative correlation with the wholesale prices of two products.

$\frac{\mathrm{dk}_{\mathrm{c}}^{*}}{\mathrm{~d} \beta}=\frac{\mathrm{w}_{\mathrm{s} 1}+\mathrm{w}_{\mathrm{s} 2}+\mathrm{C}_{\mathrm{e}} \mathrm{e}_{\mathrm{s} 1}+\mathrm{C}_{\mathrm{e}} \mathrm{e}_{\mathrm{s} 2}}{2}>0$ is indicated that the total order quantity of retailers has a positive correlation with mutual substitution of two products.

$$
\begin{gathered}
\frac{\mathrm{dq}_{\mathrm{c} 1}^{*}}{\mathrm{dw}_{\mathrm{s} 1}}=-\frac{1}{2}, \frac{\mathrm{dq}_{\mathrm{c} 2}^{*}}{\mathrm{dw}_{\mathrm{s} 2}}=-\frac{1}{2}, \\
\frac{\mathrm{dq}_{\mathrm{c} 1}^{*}}{\mathrm{dw}_{\mathrm{s} 2}}=\frac{\beta}{2}>0, \frac{\mathrm{dq}_{\mathrm{c} 2}^{*}}{\mathrm{dw}_{\mathrm{s} 1}}=\frac{\beta}{2}>0, \frac{\mathrm{dq}_{\mathrm{c} 1}^{*}}{\mathrm{~d} \beta}=\frac{\mathrm{dq}_{\mathrm{c} 2}^{*}}{\mathrm{~d} \beta}=\frac{\mathrm{w}_{\mathrm{s} 2}+\mathrm{C}_{\mathrm{e}} \mathrm{e}_{\mathrm{s} 2}}{2}>0
\end{gathered}
$$

Thus, the order quantity of each product has a negative correlation with the order quantity and their wholesale prices while positive correlation with the other's wholesale price.

\section{End.}

Proposition 3 shows under carbon cap-and-trade policies, (1) when the wholesale prices of both products increase, the total purchase quantity of retailers decreases; (2) with other factors unchanged, the total purchase quantity has a positive correlation with the substitutability of substitutable products. When the substitutability between two products increases, retailers will purchase more products to sell; while when the substitutability between two products decreases, retailers will reduce the purchase quantity of substitutable products. (3) The wholesale prices of two products have a negative correlation with their optimal purchase quantities. (4) When the wholesale price of product 1 increases, the order quantity of product 2 will increase and its increasing proportion is half of the substitutability index between two products. (5)The substitutability index between two products has a positive correlation with their optimal purchase quantities.

\section{Proportion 4}

(1) $\mathrm{q}_{\mathrm{c} 1}^{*}<\mathrm{q}_{1}^{*}, \mathrm{k}_{\mathrm{c}}^{*}<\mathrm{k}^{*}$, (2) $\mathrm{p}_{\mathrm{c} 1}^{*}>\mathrm{p}_{1}^{*}, \mathrm{p}_{\mathrm{c} 2}^{*}>\mathrm{p}_{2}^{*}$

(3) When $1<\beta<\frac{\mathrm{e}_{\mathrm{s} 2}}{\mathrm{e}_{\mathrm{s} 1}} ; \mathrm{q}_{\mathrm{c} 2}^{*}<\mathrm{q}_{2}^{*}$, when $\beta>\frac{\mathrm{e}_{\mathrm{s} 2}}{\mathrm{e}_{\mathrm{s} 1}} ; \mathrm{q}_{\mathrm{c} 2}^{*}>\mathrm{q}_{2}^{*}$.

Proof: ${ }^{*}=\mathrm{q}_{1}^{*}+\mathrm{q}_{2}^{*}=\frac{\alpha_{1}+\alpha_{2}+(\beta-1)\left(\mathrm{w}_{\mathrm{s} 1}+\mathrm{w}_{\mathrm{s} 2}\right)}{2}$.

Comparing $\mathrm{k}_{\mathrm{c}}^{*}=\frac{\alpha_{1}+\alpha_{2}-(1-\beta)\left(\mathrm{w}_{\mathrm{s} 1}+\mathrm{w}_{\mathrm{s} 2}+\mathrm{C}_{\mathrm{e}} \mathrm{e}_{\mathrm{s} 1}+\mathrm{C}_{\mathrm{e}} \mathrm{e}_{\mathrm{s} 2}\right)}{2}$ and $\mathrm{k}^{*}$, it can be known that $\mathrm{k}_{\mathrm{c}}^{*}<\mathrm{k}^{*}$, namely, under carbon cap-and-trade policies, the total order quantity of retailers drops.

According to the above hypothesis, $\mathrm{e}_{\mathrm{s} 1}>\mathrm{e}_{\mathrm{s} 2}$, and then

$\mathrm{q}_{\mathrm{c} 1}^{*}=\frac{\alpha_{1}+\beta \mathrm{w}_{\mathrm{s} 2}+\beta \mathrm{C}_{\mathrm{e}} \mathrm{e}_{\mathrm{s} 2}-\mathrm{w}_{\mathrm{s} 1}-\mathrm{C}_{\mathrm{e}} \mathrm{e}_{\mathrm{s} 1}}{2}=\mathrm{q}_{1}^{*}+\frac{\beta \mathrm{C}_{\mathrm{e}} \mathrm{e}_{\mathrm{s} 2}-\mathrm{C}_{\mathrm{e}} \mathrm{e}_{\mathrm{s} 1}}{2}<\mathrm{q}_{1}^{*}$. Thus, the order quantity of product $S_{1}$ decreases. Similarly, when $\beta<\frac{e_{\mathrm{s} 2}}{e_{\mathrm{s} 1}}$, the order quantity of product $S_{2}$ drops, when $\beta>\frac{e_{s 2}}{e_{s 1}}$, the order quantity of product $\mathrm{S}_{2}$ increases.

It can be known from Formula (7) that $p_{\mathrm{c} 1}^{*}=p_{1}^{*}+\frac{\mathrm{C}_{\mathrm{e}} \mathrm{e}_{\mathrm{s} 1}}{2}, \mathrm{p}_{\mathrm{c} 2}^{*}=\mathrm{p}_{2}^{*}+\frac{\mathrm{C}_{\mathrm{e}} \mathrm{e}_{\mathrm{s} 2}}{2}$. The more the carbon emission of retailers in logistics link is, the higher the product price is.

End.

Proposition 4 shows that (1) compared with the case under carbon-free constraints, carbon cap and trade policies will influence total purchase quantity of retailers and may lead to the drop of product purchase quantity. (2) If carbon emission costs of retailers are increased, the wholesale price of two products will improve. (3) Compared with the case under carbon-free constraints, the purchase quantity of product 2 mainly depends on the shifting threshold of substitutability between two products $\frac{\mathrm{e}_{\mathrm{s} 2}}{\mathrm{e}_{\mathrm{s} 1}}$, The coefficient of the substitutability between two products is relevant to the ratio of carbon emission of two products. When the substitutability coefficient of two products $\beta$ is greater than the threshold, the purchase quantity of products will increase.

Lemma 1. Under carbon cap-and-trade policies, carbon emission of product $S_{1}$ in the transportation and sales links decreases and total carbon emission of retailers drops. When $\beta<\frac{\mathrm{e}_{\mathrm{S} 2}}{\mathrm{e}_{\mathrm{s} 1}}$, the carbon emission of product $\mathrm{S}_{2}$ decreases; while when $\beta>\frac{e_{s 2}}{e_{s 1}}$, the carbon emission of product $S_{2}$ increases.

Proportion 5Under carbon cap-and-trade policies.

(1) $\frac{\mathrm{dq}_{\mathrm{c} 1}^{*}}{\mathrm{dA}}=\frac{\mathrm{dq}_{\mathrm{c} 2}^{*}}{\mathrm{dA}}=0 ; \frac{\mathrm{d} \pi_{\mathrm{c}}^{*}}{\mathrm{dA}}=\mathrm{C}_{\mathrm{e}}$

(2). $\frac{\mathrm{dk}_{\mathrm{c}}^{*}}{\mathrm{de}_{\mathrm{s} 1}}=\frac{\mathrm{dq}_{\mathrm{c} 2}^{*}}{\mathrm{de}_{\mathrm{s} 2}}<0, \frac{\mathrm{dk}_{\mathrm{c}}^{*}}{\mathrm{dC}_{\mathrm{e}}}<0$;

(3) $\mathrm{e}_{\mathrm{s} 1}>\mathrm{e}_{\mathrm{s} 2}, \frac{\mathrm{dq}_{\mathrm{c} 1}^{*}}{\mathrm{dC}_{\mathrm{e}}}<0$, when $\beta<\frac{\mathrm{e}_{\mathrm{s} 2}}{\mathrm{e}_{\mathrm{s} 1}}, \frac{\mathrm{dq}_{\mathrm{c} 2}^{*}}{\mathrm{dC} \mathrm{e}_{\mathrm{e}}}<0$, when $\beta>\frac{\mathrm{e}_{\mathrm{s} 2}}{\mathrm{e}_{\mathrm{s} 1}}$, $\frac{\mathrm{dq}_{\mathrm{c} 2}^{*}}{\mathrm{dC}_{\mathrm{e}}}>0$.

Proof: According Formula (5) and (6), it can be known that,

$\frac{d q_{c 1}^{*}}{d A}=\frac{d q_{c 2}^{*}}{d A}=0, \frac{d \pi_{c}^{*}}{d A}=C_{e}>0$, carbon cap has few influences on the order strategy of retailers and retailer profit has a positive correlation with carbon cap.

$$
\begin{gathered}
\frac{\mathrm{dq}_{\mathrm{c}}^{*}}{\mathrm{de}_{\mathrm{s} 1}}=\frac{\mathrm{dq}_{\mathrm{c} 2}^{*}}{\mathrm{de}_{\mathrm{s} 2}}=\frac{-(1-\beta) \mathrm{C}_{\mathrm{e}}}{2}<0, \\
\frac{\mathrm{dq}_{\mathrm{c}}^{*}}{\mathrm{dC}_{\mathrm{e}}}=\frac{-(1-\beta)\left(\mathrm{e}_{\mathrm{s} 1}+\mathrm{e}_{\mathrm{s} 2}\right)}{2}<0, \frac{\mathrm{dk}_{\mathrm{c}}^{*}}{\mathrm{dC}_{\mathrm{e}}}<0
\end{gathered}
$$

According to the above hypothesis, if $\mathrm{e}_{\mathrm{s} 1}>\mathrm{e}_{\mathrm{s} 2}$, $\frac{\mathrm{dq}_{\mathrm{c} 1}^{*}}{\mathrm{dC}_{\mathrm{e}}}=\frac{\beta \mathrm{e}_{\mathrm{s} 2}-\mathrm{e}_{\mathrm{s} 1}}{2}<0, \frac{\mathrm{dq}_{\mathrm{c} 2}^{*}}{\mathrm{dC}_{\mathrm{e}}}=\frac{\beta \mathrm{e}_{\mathrm{s} 1}-\mathrm{e}_{\mathrm{s} 2}}{2}$. Thus, the optimal order quantity of product $S_{1}$ has a negative correlation with carbon trade 
price; when $\beta<\frac{e_{s 2}}{e_{s 1}}$, the optimal order quantity of product $\mathrm{S}_{2}$ has a negative correlation with the carbon trade price; when $\beta>\frac{e_{s 2}}{e_{s 1}}$, the order quantity of product $S_{2}$ has a positive correlation with the carbon trade price.

\section{End.}

Proposition 5 demonstrates that (1) under carbon cap-and-trade policies, the purchase quantity of products has no correlation with initial carbon quota and the initial carbon quota given by the government is equivalent to "welfares". Thus, though the total purchase of retailers drops, profits may be higher than that under carbon-free constraints because of high carbon quota by the government. (2) The total purchase quantity of retailers has a negative correlation with carbon emission and carbon trade price of products. (3) It is supposed that if $\mathrm{e}_{\mathrm{s} 1}>\mathrm{e}_{\mathrm{s} 2}$, the optimal order quantity of product 1 has a negative correlation with carbon trade price. Thus, for product 2 , with the increase of carbon trade price, its purchase quantity is not necessarily restricted. Its change depends on the shifting threshold of substitutability between two products, $\frac{\mathrm{e}_{\mathrm{s} 2}}{\mathrm{e}_{\mathrm{s} 1}}$. When the substitutability of products is high, the increase of carbon trade can lead to the increases of product purchase quantity and the optimal purchase quantity of products with small carbon emission in the transportation and sales links, manifesting the positive promotion of carbon cap-and-trade policies on low-carbon products.

\section{CONCLUSION}

This paper studies the order and pricing strategies of retailer double-source purchase of substitutable products by two manufacturers and with different carbon emissions in the transportation and sales links under carbon cap-and-trade policies. This study indicates that, 1) carbon cap-and-trade policies may lead to the decrease of the total order quantity of retailers and the increase of the retail price. For product 2, its purchase quantity change depends on the shifting threshold $\left(\frac{\mathrm{e}_{\mathrm{s} 2}}{\mathrm{e}_{\mathrm{s} 1}}\right)$. Profits may be higher than that under carbon-free constraints because of high carbon quota by the government.2) If there is substitutability between two products, the total purchase quantity has a positive correlation with the substitutability of two substitutable products while negative correlation with the wholesale price and carbon trade price. With the increase of carbon trade price, the order quantity of product 2 is not necessarily restricted. Its change depends on the shifting threshold $\left(\frac{e_{\mathrm{s} 2}}{e_{\mathrm{s} 1}}\right)$. When the substitutability of a product is high, the optimal purchase quantity of products with low carbon emission increases, manifesting the positive promotion of carbon cap-and-trade policies on low-carbon products. This study not only provides decisions for retailer goods supply selection, pricing and order, not only gives theoretical supports for the formulation of carbon emission policies by the government. In future studies, the vertical expansion of single retailers to the supply chain shall be considered, as well as the joint decision of manufacturers and retailers.

\section{ACKNOWLEDGMENT}

The authors would like to thank the editors and the anonymous reviewers for their insightful and constructive comments and suggestions that have led to this improved version of the paper. The work was supported in part by the "Chunhui" Plan of Ministry of Education in China (No. S2011012 and No. Z2012017).

\section{REFERENCES}

[1] H. Cheryl, J. Jeff, K. Jyllian, "Global-warming warnings," Chemical \& Engineering News, vol. 91, no. 3, pp. 4, 2013.

[2] B.Sundarakani, R. D. Souza, M. Goh, et al, "Modeling carbon footprints across the supply chain," International Journal of Production Economics , vol. 128, no. 1, pp. 43-50, 2010.

[3] Eurostat, Panorama of Transport, online, http://epp.eurostat.ec.europa.eu/cache/ITY_OFFPUB/KS-DA-09-001/E N/KS-DA-09-001-EN.PDF. 2009.

[4] G. Hua, T. C. E. Cheng, and S. Wang, "Managing carbon footprints in inventory management," International Journal of Production Economics, vol. 132, no. 2, pp. 178-185, 2011.

[5] X. Chen, S. Benjaafar, A. Elomri, "TheCarbon-Constrained EOQ ," Operations Research Letters, vol. 41, no. 2, pp. 172-179, 2013.

[6] T. M.Choi, "Carbon footprint tax on fashion supply chain systems," International Journal of Advanced Manufacturing.vol. 68, no. 4, pp. 835-847, 2013.

[7] M.Jin,N.A.Granda, and I. Down, "The impact of carbon policies on supply chain design and logistics of a major retailer," Journal of Cleaner Production, vol. 85, pp. 453-461, 2014.

[8] H.Rosic, W. Jammernegg, "The economic and environmental performance of dual sourcing: A newsvendor approach," International Journal of Production Economics, vol. 143, no. 1, pp. 109-119, 2013.

[9] P. He, W. Zhang, X. Xu, et al, "Production lot-sizing and carbon emissions under cap-and-trade and carbon tax regulations," Journal of Cleaner Production, vol.103, pp. 241-248, 2014.

[10] J. Zhang, T. Nie, S. Du, "Optimal emission-dependent production policy with stochastic demand," International Journal of Society Systems Science, vol. 3, no. 1-2, pp. 21-39, 2011.

[11] Z. Hong, C. Chu, Y. Yu, "Optimization of production planning for green manufacturing ," 9th IEEE International Conference on Networking, Sensing and Control (ICNSC), Paris, Frances, pp. 193-196, 2012

[12] F. C. Giraud-Carrier. Pollution regulation and production in imperfect markets [D]. The University of Utah, 2014. 